\title{
Skam æder anerkendelser op - præsentation af et skjult ledelsesproblem ved stress
}

\author{
Af Pernille Steen Pedersen *)
}

\section{Resumé}

Denne artikel præsenterer skam som et nyt og skjult ledelsesproblem. Med afsæt i kvalitative interviews fra to forskellige forskningsprojekter viser jeg, hvordan skam dukker op i et moderne arbejdsliv i forbindelse med stress. Efter at have præsenteret forskningsprojekterne og min analysetilgang, viser jeg forskellige situationer, hvori skamfølelsen dukker op som et ledelsesproblem. Herefter introduceres to reaktionsmønstre på skam som afsæt til, at jeg afslutningsvis kan pege på relationen og kommunikationen mellem leder og medarbejder samt kollegaer indbyrdes som stedet, hvor skamfølelsen kan håndteres med henblik på at forebygge yderligere forværring af skam. Målet med artiklen er at kaste lys over en ny problemstilling i forbindelse med stress, som jeg fortsat er i gang med at udforske. Artiklen skal betragtes som en invitation til at få indblik i en opdagelsesrejse, med de forbehold det nu engang indebærer. Jeg håber, at læseren vil tage med på rejsen og bruge den præsenterede viden som inspiration til eget arbejde - frem for at betragte den som en fiks og færdig teori.

*) Pernille Steen Pedersen er ph.d. og ansat som Post.doc på Institut for Ledelse, Politik og Filosofi på CBS. Har gennem en årrække beskæftiget sig med, hvordan ledelse kan tilrettelægges mhp. at håndtere medarbejdernes stressrelaterede problemstillinger med særlig fokus på undersøgelse af skammens betydning som en ny og fremtrædende problematik i forhold til stress. ppe.mpp@,cbs.dk,www.sundledelse.dk 


\section{A. Indledning}

\section{Baggrund}

"Hun sammenligner sig selv med resten af verden, så hvis hun ikke hvert eneste år er den bedste, så kan jeg sige til hende nok så meget, at jeg er tilfreds med, at hun bliver nummer fem i år. Det er hun ikke. Hun ser efter de 5 bedste og sætter sin egen overligger ti centimeter højere, når hun føler skam. Og hun føler skam, fordi hun ikke hopper over sin egen overligger."

Sådan sætter en leder ord på det, han betragter som én af de allerstørste problemstillinger ift. at håndtere medarbejdere i risiko for at blive stresssygemeldte. Denne oplevelse står han ikke alene med, og som vi skal se, indfanger den en central ledelsesudfordring inden for et meget komplekst område. For stress fylder på danske arbejdspladser og det i en grad, som får nogle forskere til at bruge ordet "stress-epidemi”. 430.000 danskere oplever iflg. Stressforeningens hjemmeside dagligt symptomer på alvorlig stress, og Verdenssundhedsorganisationen WHO forudser, at stress sammen med depression vil blive en af de største sygdomsfaktorer i år 2020. I den seneste tid er der kommet et øget fokus på lederens rolle i forhold til at håndtere stress i arbejdslivet (Andersen og Kingston, 2016; Borg et al. 2009; Ladegaard et al., 2017; OECS, 2015). ”Dårlig ledelse udløser stress” lyder overskriften på en artikel i DJØF-bladet i januar 2017, mens Det Nationale Forskningscenter for Arbejdsmiljø (NFA) i en undersøgelse fra 2016 konkluderer, at "manglende ros og anerkendelse fra chefen kan udløse depression". Stress er med andre ord blevet et ledelsesansvar, og der er således god grund til at se nærmere på de ledelsesproblemer, der er forbundet med at forebygge og håndtere stress blandt medarbejdere. I stedet for at udpege ledere til de store syndere, finder jeg det mere konstruktivt som forsker også at undersøge, dels hvad der karakteriserer de problemer, som ledelse kan forholde sig til/være løsning på, når rammer og normeringer fastlægges uden for lederens rækkevidde, og dels hvad ledere så kan gøre for at håndtere disse problemer.

\section{Problemstillinger og formål}

I min forskning har jeg belyst én af de problemstillinger, som ledelse kan håndtere, og som ikke hidtil har fået opmærksomhed i litteraturen, nemlig skamfølelsen. I den eksisterende ledelsesforskning antydes en sammenhæng mellem stress og skam (Lazarus, 2006 s. 253, 282, 289; Matzau, 2009 s. 46), men en nærmere belysning af karakteren af skammens effekter og skammens rolle i en arbejdsmæssig kontekst er imidlertid mangelfuld. Formålet med artiklen er at 
introducere skam som en central følelse i forbindelse med stress i et moderne arbejdsliv og give ledere indblik i de indre konflikter, medarbejdere kan opleve, og som samtidig udfordrer lederens adgang til at påvirke medarbejderen. Igennem artiklen anvender jeg citater fra ledere og fra medarbejdere til at illustrere mine pointer. Efter en præsentation af de to forskningsprojekter, som ligger til grund for artiklen samt min analysetilgang, tager jeg læseren med på den rejse, hvori jeg opdagede skamfølelsen og de forskellige måder, hvorpå skam viser sig i arbejdslivet. Jeg præsenterer i forlængelse heraf ét af hovedfundene i min forskning, nemlig de to forskellige reaktionsmønstre: problemløser og relationsmester. Afslutningsvis peger jeg på relationen og kommunikationen mellem leder og medarbejder samt kollegaer indbyrdes som stedet, hvor skamfølelsen kan håndteres med henblik på at forebygge yderligere forværring af skam. For en nærmere redegørelse af det teoretiske grundlag bag mine analyser henvises til ph.d.-afhandlingen: "Udkast til et nyt copingbegreb - en kvalifikation af ledelsesmuligheder for at forebygge sygefravar ved psykiske problemer" (Pedersen, 2016a).

\section{B. Det empiriske materiale: To forskningsprojekter}

Artiklen bygger på empirisk materiale fra to forskningsprojekter. Det første forskningsprojekt var mit ph.d. projekt (Pedersen, 2016a), hvor jeg for første gang begrebssatte følelsen af skam som et nyt ledelsesproblem, mens jeg i det andet forskningsprojekt nu afprøver og videreudvikler viden og værktøjer til at håndtere skam.

\section{Forskningsprojekt 1}

Mellem sommeren 2012 og efteråret 2015 blev der gennemført 32 kvalitative interviews med ledere og med medarbejdere fra forskellige brancher, både offentlige og private virksomheder. 16 interviews blev gennemført med medarbejdere, der enten var eller havde været langtidssygemeldt med psykiske problemer som stress, mens 12 interviews blev gennemført med ledere. Fire interviews blev gennemført med medarbejdere, der havde oplevet psykiske problemer, men som ikke havde været sygemeldte. Der var kun ét foruddefineret spørgsmål. De interviewede ledere blev bedt om at fortælle om deres erfaringer med at håndtere medarbejdere, der var endt med at blive sygemeldte, mens de interviewede medarbejdere blev bedt om at fortælle om forløbet op til deres sygemelding. 


\section{Forskningsprojekt 2}

I forbindelse med dette forskningsprojektet er der foretaget interviews i to omgange, hhv. før og efter at deltagerne har fået præsenteret materialer. I vinteren 2017/18 blev der gennemført 46 kvalitative interviews med ledere og med medarbejdere i tre kommuner, hvoraf de 14 interviews var med ledere. Halvdelen af de interviewede medarbejdere havde selv haft stress inde på livet, hvorimod den anden halvdel ikke havde. Fremgangsmåden for interviewene var den samme som i det første forskningsprojekt, dog med to forskelle: 1) Der blev stillet spørgsmål til kollegiale udfordringer ift. at støtte og hjælpe kollegaer med stress, 2) I anden halvdel af interviewet blev de interviewede præsenteret for fundet af skam mhp. at kommentere herpå. Efter afprøvningen blev der i efteråret 2018 gennemført 17 kvalitative interviews og fire fokusgruppeinterviews med medarbejdere, samt to fokusgruppeinterviews og tre kvalitative interviews med ledere. Fokus i disse interviews var på at vurdere materialet og tilgangen til stressforebyggelse (Se boks nederst for nærmere beskrivelse af forskningsprojektet).

\section{Metode}

I begge forskningsprojekter blev interviewene gennemført i overensstemmelse med anvisningerne for det diskursive interview (Kvale og Brinkmann, 2009), hvilket indebar, at jeg som interviewer lagde vægt på "teknikker, som tillader forskellighed, frem for teknikker, der eliminerer den, hvilket kan resultere i mere uformelle ordvekslinger" med interviewerne "som aktive deltagere snarere end som talende sporgeskemaer" (Potter og Weltherell citeret i Kvale og Brinkmann, 2009, s. 176). Jeg transskriberede selv alle interviews og analyserede dem med udgangspunkt i en analysemodel, jeg og en kollega har udviklet med afsæt i den franske filosof og sociolog Michel Foucaults problematiseringsanalyse (Foucault, 1985). Problematiseringsanalyse handler om at belyse måden, hvorpå noget (for eksempel en bestemt type adfærd, visse fænomener eller processer) optræder som et problem, og hvordan det overhovedet er blevet til et problem - ofte på forskellige måder inden for forskellige diskurser (Raffnsøe et al., 2015). (For en uddybning af analysemodellen se Pedersen og Krarup, 2018).

\section{Skam}

Den første kodning og analyse af materialet i forskningsprojekt 1 fører til, at jeg kan iagttage, at der i alle de forløb, som er endt med en stressrelateret sygemelding, på et tidspunkt har været en 
forandring på arbejdspladsen eller privat, der indebærer, at medarbejderen skal gå på kompromis med sine egne krav til, hvordan opgaverne skal løses. Typiske forandringer i arbejdslivet er organisationsændringer, forandringer ift. opgaveløsninger, besparelser, sammenlægning af medarbejdergrupper og ændringer i ledelsen, mens typiske forandringer i privatlivet er skilsmisse, dødsfald eller sygdom i nærmeste familie eller at få børn. Forandringen kræver, at medarbejderen skal levere, hvad der opleves som "80 procent-præstationer", enten fordi virksomheden kræver dette, eller fordi de private problemer tærer så meget på kræfterne, at det ikke er muligt at præstere som hidtil. Dette indebærer, at medarbejderen må give afkald på nogle anerkendelser, som fulgte med de hidtidige (i medarbejderens øjne ”bedre”) præstationer.

Et gennemgående mønster i de forløb, der er endt i en sygemelding, er, at denne uoverensstemmelse mellem medarbejderens ideal og de faktiske muligheder og det ledsagende "anerkendelsestab" skaber en indre konflikt i medarbejderen, som opleves som en moralsk konflikt, fordi den lavere opgaveløsning er ledsaget af en følelse af at føle sig forpligtet på at levere mere, end hvad der er muligt på det pågældende tidspunkt og derudover en oplevelse af ikke at slå til. "Problemet var ikke arbejdspresset. Det var ikke timerne. Det var mere det psykologiske i ikke at fole, at man slog til. At man ikke kunne prastere det, der blev forventet", siger en medarbejder og sætter dermed ord på et tilbagevendende problem: Oplevelsen af ikke at kunne leve op til egne eller andres forventninger, eller rettere: Det man tror, at andre forventer af én. Medarbejderen bedømmer sig selv mod et urealistisk målestok og kompenserer for oplevelsen af ikke at leve op til forventninger ved f.eks. at bruge for lang tid på opgaverne og løse dem grundigere end det fra virksomheden fastsatte, eller de giver udtryk for deres frustrationer på måder, som bliver oplevet som ”brok”.

En overraskende og central problemstilling viser sig i sammenhæng med den moralske konflikt: I takt med at medarbejderens usikkerhed vokser, og det bliver tiltagende sværere for medarbejderen at anerkende sine egne præstationer, så bliver det også tiltagende vanskeligere at tage imod anerkendelse og feedback fra lederen. Dette citat illustrerer denne pointe:

”Jeg kunne slet ikke modtage min leders anerkendelse af mit arbejde. Jeg gjorde hende opmærksom på, at den ros, hun gav mig, faktisk ikke var fortjent. Min leder forsøgte at gøre mig klart, at hun mente det. Jeg kunne godt høre, hvad hun sagde til mig, og jeg var bestemt også glad for det, men jeg blev ved med at have følelsen af, at det var ufortjent, og at jeg havde "snydt" hende." 
Vi ser her en medarbejder, der hører lederens ord og alligevel hjælper denne anerkendelse ikke, for det sagte (anerkendelsen) trænger ikke ind (bearbejdes ikke bevidst), også selvom medarbejderen faktisk forstår. På tilsvarende vis fortæller en anden medarbejder, hvordan hun “modtog masser af anerkendelse", men at hun samtidig "følte sig som en logner", når hun fik anerkendelse. Disse udtalelser er forskellige, men ved at sammenholde dem ser jeg, at de er struktureret omkring en problemstilling, som jeg koder ved navnet: "Anerkendelsesparadoks". Her foregår der en "indre kamp", hvor usikkerheden dominerer, og medarbejderen langsomt begynder at foregribe sig selv som én, der fejler. "Bare tanken om at skulle stille sig op og prasentere noget, der tror jeg, at alle ville have gennemskuet mig", fortæller en medarbejder og sætter her ord på endnu et gennemgående træk: Frygten for at blive afsløret eller gennemskuet. Denne afsløringsangst er ledsaget af en tiltagende selvkritik, der af flere beskrives som en indre stemme, der som en dommer vurderer og bedømmer både egen og andres opførsel ud fra en selvkritisk målestok. "Ja, den kører hele tiden. Det er jo den, der gør dig stresset. Det er jo helt klart. Det er rigtig interessant. Man bliver i tvivl om sig selv, og man tanker, at det så nok bare er mig, der er tosset", udbryder en medarbejder.

På dette sted i analysen bringer jeg begrebet skam ind til at samle disse udtalelser med fokus på den indre moralske dom: "Du er ikke god nok til dette, du er ikke vardig til det, du vil blive afsloret for eller siden - det er din egen skyld’. Det er som om fornuften nærmest overdøves, hvilket medarbejdere, der har oplevet stress, kan genkende. "Jeg kan ikke forestille mig et andet ord, der er bedre dakkende end skam. For mig er skam det fineste ord, altså den rummer så meget flovhed og mindrevard over faktisk godt at kunne se det rationelle i mange ting, men ikke at kunne udleve det eller handle derefter", siger en medarbejder.

I forbindelse med stress i arbejdslivet og en leders mulighed for at støtte medarbejdere bliver skammens evne til at kunne overdøve fornuftens stemme et ledelsesproblem, fordi den gør det svært for medarbejderen at modtage anerkendelse og feedback fra andre. "Det er rigtig", udbryder en medarbejder, efter at jeg har fortalt om denne funktion. "Det har jeg også oplevet. Jeg kan slet ikke tage imod anerkendelser, når jeg er stresset, og skammen har smidt sit filter ind i mig", mens en leder omtaler sit forsøg på at overbevise en medarbejder om, at hans præstation er god nok: "Det var umuligt for mig at trange igennem. Det var vand på en gås.” 
Skammens produktive element og konsekvenserne ift. at kunne modtage anerkendelse berøres ikke i den eksisterende litteratur, der godt nok fremhæver forskellen mellem skyld og skam ved at knytte skyld til det, man gør, til handlinger, og skam til det, man er (Lazarus, 2006, p. 290; Lewis, 1971; 2013; Tangney et al., 2007), men ikke udforsker skammens hæmmende effekt i forhold til anerkendelser. Det er imidlertid væsentligt, at der er tale om en udvikling, hvori såvel tanker og opførsel ændrer sig, i takt med at skammen bliver mere larmende og hæmmende (For uddybning af denne pointe henvises til Pedersen og Gudmand-Høyer, 2017). Dette skema i figur 1 har til formål at vise udviklingen i en skamreaktion:

\begin{tabular}{|l|l|l|}
\hline & Tanker & Opførsel \\
\hline & $\begin{array}{l}\text { Jeg er ikke, som jeg gerne vil være - jeg } \\
\text { lever ikke op til mine egne eller andres } \\
\text { forventninger }\end{array}$ & $\begin{array}{l}\text { Arbejder for meget, ofte til langt ud på } \\
\text { natten }\end{array}$ \\
\hline & $\begin{array}{l}\text { Jeg bebrejder mig selv for det, jeg } \\
\text { frygter vil ske, for jeg har gjort noget, } \\
\text { jeg ikke bør gøre - jeg har gjort noget } \\
\text { forkert }\end{array}$ & $\begin{array}{l}\text { Engstelig og overdreven opmærksomhed } \\
\text { på performance eller på hvad andre siger }\end{array}$ \\
\hline & $\begin{array}{l}\text { Jeg er bange for at blive afsløret. } \\
\text { Tankerne afviser alt, der ikke stemmer } \\
\text { med den indre oplevelse af skam, og } \\
\text { skaber et fængsel uden vej ind eller ud } \\
\text { jeg skader andre }\end{array}$ & Flugtadfærd; fysisk isolation \\
\hline
\end{tabular}

Figur 1: Udviklingen i en skamreaktion

Skemaet illustrerer udviklingen i en skamreaktion. Som processen skrider fremad, udskilles en alternativ virkelighed som referencepunkt; en privat virkelighed, som kun man selv kender, og som indebærer, at det bliver vanskeligere og vanskeligere at opnå en følelse af at gøre det godt nok, samtidig med at det bliver tiltagende sværere at tage imod omgivelsernes input. Dette har fået mig til at se på skam som en følelsesmæssig reaktion med en funktion, hvor skam f.eks. kan bremse anerkendelser.

\section{To reaktionsmønstre på skam}

Mine undersøgelser har vist, at der er forskellige kilder til skam og forskellige måder at håndtere skam. Det får afgørende indvirkning på, hvordan man som leder kan støtte og hjælpe en medarbejder til at kunne modtage anerkendelse. Jeg har i den forbindelse begrebssat to 
copingmekanismer, i det følgende kaldet reaktionsmønstre. Ved at anvende ordet "copingmekanisme" understreges, at der ikke er tale om personlighedstyper. Som menneske besidder vi begge reaktionsmønstre, så man i nogle situationer kan reagere i overensstemmelse med det ene mønster, mens man i andre situationer reagerer i overensstemmelse med det andet mønster. Med andre ord er der fokus på reaktionerne på situationer, og som generelle begreber kan de kaste lys over, at det er forskellige situationer, der kan fremkalde stress, fordi vi belastes forskelligt af de samme input, men også at vi ikke opfatter anerkendelser på samme måde. Jeg har set mange eksempler på at det, der opleves som en anerkendelse for én, kan blive opfattet som et overgreb eller en krænkelse for en anden. En leder nikker, da jeg nævner denne iagttagelse og siger: "Ja, det kan betyde rigtig meget for nogen, når de små ting bliver bemarket $i$ hverdagen, som "skide godt", "godt tankt", "fortsat", mens andre har det helt omvendt og narmest kan blive irriteret over at få anerkendelse for ting, de godt ved i forvejen".

Jeg kalder det første reaktionsmønster problemløser. Det, der her karakteriserer situationer med et skamfremkaldende potentiale, er egne krav i kombination med ydre krav om at gå på kompromis med egne krav til en opgaveløsning, for her er skammen og den indre moralske dommer særligt optaget af at bedømme præstationen. Når dette reaktionsmønster er på spil, kan det være svært at bede om hjælp og at tage imod hjælp fra andre, fordi man er bange for at "blotte" sig og vise svaghed. Her er en illustrativ udtalelse på reaktionsmønstret problemløser:

”Jeg er bange for, at de andre skal se, hvor forfærdeligt det er, det jeg laver. Jeg er bange for at blive afsløret i slet ikke at have styr på det, og jeg tænker, at de andre har forventninger om, at jeg kan mere, end jeg kan, og det er pinligt, simpelthen pinligt, at jeg ikke kan løse den her. Jeg knokler og knokler. Jeg arbejder til langt ud på natten. Det er sygt. Jeg kan ikke finde ud af at stoppe. Men jeg elsker det også. Jeg kan ikke finde balancen.”

Jeg kalder det andet reaktionsmønster relationsmester. Det, der her karakteriserer situationer med et skamfremkaldende potentiale, er både egne krav, men især også andres opførsel, fordi skamfølelsen her i højere grad knyttet til forholdet til andre mennesker, f.eks. en leder eller en kollega og vurderingen af, om man bliver behandlet med respekt, og om andre kan lide én. Her kan konflikter og situationer, hvor man fremkalder modvilje eller uenighed, give anledning til 
usikkerhed og tvivl på eget værd. Her er en illustrativ udtalelse på reaktionsmønstret relationsmester.

"Hvad siger de om mig bag min ryg, når jeg ikke er der". Der har de jo i min optik været der og snakket grimt om mig. Og jeg følte virkelig, da jeg kom ind, den der med "åh gud, der kommer hun nu igen, hvad har hun af undskyldninger”. Det var den der indgangsvinkel, de kom med. Og den kom også lidt fra ledelsen på samme måde."

Hvor skammen ved reaktionsmønstret problemløser bliver vakt af medarbejderens dom over sin egen præstation, bliver skammen i reaktionsmønstret relationsmester vakt i en kombination af dom over sig selv, men også af andres opførsel. Den første medarbejder er fanget mellem udbrændthed og oplevelsen af personligt nederlag, den anden medarbejder føler sig socialt udenfor. (En uddybning af reaktionsmønstrene findes i Pedersen, 2016 a og b). Spørgsmålet, der nu melder sig, er: "Hvordan kan ledere støtte medarbejdere i at kunne modtage anerkendelse"?

\section{E. Lederen som vikarierende samvittighed}

For at støtte medarbejderen i at kunne modtage anerkendelser i situationer, hvor der er en indre konflikt og en skamfølelse, der kan fungere som et "filter", er det ikke tilstrækkeligt at have fokus på at give klare ordrer eller anerkende medarbejderen, som man plejer (Pedersen, 2016a). For skammens produktive natur kan overdøve fornuftens stemme. Jeg kan pege på, at det for det første er helt afgørende at understøtte en kultur, der anerkender fejl som noget, der sker, og som man tager ved lære af, og f.eks. hylder månedens ”fejl” i stedet for ”månedens medarbejder”. For det andet foreslår jeg, at lederen medierer i konflikten og hjælper medarbejderen til at kunne modtage anerkendelser. Jeg foreslår, at lederen optræder som vikarierende samvittighed og for en tid overtager domsfunktionen som led i at støtte medarbejderen til at kunne gå på kompromis med sit ideal uden at være bange for at blive afsløret. For at få denne medierende adgang til konflikten, er det imidlertid nødvendig at tilpasse ledelsesstilen efter de to reaktionsmønstre.

Ved problemløserreaktioner er skammen forbundet med medarbejderens hårde bedømmelse af, om præstationen er god nok. Her foreslår jeg, at lederen f.eks. kan være vikarierende samvittighed 
ved at beskrive, hvad forventningen til opgaveløsningen er og hjælpe medarbejderen til at se de faglige argumenter ved at præsentere de faglige overvejelser, der ligger bag og derefter sige:

”Det er mit ansvar som leder, at opgaven er afgrænset på denne her måde. Jeg kan godt se, at opgaven ville blive løst mere grundigt, hvis du får mere tid, men lige nu er dette her en 100 procent opgaveløsning ud fra det nuværende mulighedsrum. Lad mig høre dine input til, hvordan vi fortsat kan have fokus på at bringe din faglighed i spil inden for denne her ramme."

Her fremstiller lederen budskabet: "Der er ikke noget i vejen med at ville præstere 100 procent, og det kan godt ske her, men på en lidt anden måde, fordi der nu afkræves en anden standard”. Medarbejderens egne krav bliver modificeret i samspil mellem leder og medarbejder, men de overses netop ikke. Lederen siger ikke: ”Du skal lade være med at være så grundig, det er godt nok, som det er", men arbejder med og ikke mod de krav og indre forventninger, der skal modificeres. Samtidig overtager lederen for en tid domsfunktionen ved tydeligt at melde ud, hvad forventningerne er (jf. Pedersen, 2016b, s. 135-167).

Ved relationsmesterreaktioner er skammen forbundet med en indre bedømmelse af andres opførsel og andres respekt, ofte en leder eller kollega(r). Her kan der optræde en følelse af at være misforstået, og den truende situation er således ofte knyttet til lederen selv eller en kollega, hvilket kan gøre ledelsesindsatsen svær. En måde at støtte medarbejderen på er at lytte tålmodigt til medarbejderens bekymringer og tage dem alvorligt uden at bedømme dem (f.eks. ved at sige. ”Jamen det skal du ikke tænke på, det er da ikke så slemt”). Lederen viser, at han eller hun lytter ved at stille uddybende spørgsmål eller ved at gentage det, som medarbejderen har sagt. Denne strategi med at gentage og stille uddybende spørgsmål kan imidlertid have kontraproduktive effekter i tilfælde af problemsløserreaktioner, fordi medarbejderen her kan føle, at lederen ikke er klar i sin udmelding. Ved relationsmesterreaktioner kan det derimod virke beroligende på medarbejderen og understøtte oplevelsen af, at lederens intention er at forstå medarbejderen. Små ord som ”Jeg står bag dig”, ”jeg tager din ryg”, eller ”jeg ved, at du arbejder hårdt” kan gøre en stor forskel (For uddybning af de konkrete forslag til ledelsesløsninger henvises til Pedersen, 2016b). 
Denne foregribende indsats med fokus på, hvordan kommunikation mellem leder og medarbejder kan tage højde for de to reaktionsmønstre, kræver, at begge parter, både leder og medarbejder, får viden om de forskellige måder at reagere på, så der kan ske en fælles dialog herom. Medarbejdere har også et ansvar for at støtte ledere til at kunne give den ledelse, der er brug for i den pågældende situation.

Til at hjælpe dialoger på vej har jeg i mit nye forskningsprojekt udviklet en række spørgsmål, som ledere og medarbejdere samt kollegaer indbyrdes kan tage afsæt i ift. at tale om forskellige måder at støtte hinanden. F.eks. fremlægger jeg en række udtalelser fra min empiri, som ledere og medarbejdere kan bruge som afsæt for deres dialog. Her er to udtalelser, som viser to forskellige måder, hvorpå en leder kan støtte en medarbejder: Udtalelse 1: ”Jeg vil gerne have, at min leder først kommer, når jeg selv beder om det”. Udtalelse 2: ”Jeg vil gerne have, at min leder kommer uopfordret og f.eks. spørger til, hvordan det går”. Pointen er så, at leder og medarbejder med afsæt i den fælles viden, som jeg også har præsenteret, dernæst kan drøfte udtalelser som disse mhp. i et fællesskab at skabe grobund for den relevante ledelsesindsats.

\section{F. En ny anerkendelsespraksis}

I forskningsprojekt 2 har ledere og medarbejdere testet materiale, der netop har haft til formål at klæde begge parter på med viden til at blive klogere på og have dialoger omkring forskellige ledelsesbehov i situationer, hvor medarbejderne oplever moralske konflikter. Det har været spændende i dette forskningsprojekt at udvikle min tilgang sammen med dem, der skal anvende den. Det har bidraget til, at jeg nu kan arbejde videre mhp. at udvikle det, jeg har fundet ud af er en ny anerkendelsespraksis. Det var ikke mig selv, men Martin fra Nordsjællands Hospital, der gjorde mig opmærksom på, at det var det, jeg var i færd med, da han spurgte mig:

"Pernille, er du ikke ved at udvikle en anerkendelsespraksis med en nuanceret forståelse af den indre psykologis møde med den ydre verden - herunder en leder og hvad sker der i dette møde? Et sprog for dilemma, som den enkelte har inden i sig selv - som leder og som kollega kan man tage noget af trykket væk og forflytte konflikten fra den indre kampplads til en ydre arene, hvor vi ikke kun selv er egen værste dommer." 
Og ja, det er præcis det, jeg er i færd med, og jeg er slet ikke færdig, men jeg kan se, at især mine beskrivelser af den larmende og lammende skam samt de to reaktionsmønstrene kan hjælpe til, at vi kan se mennesket bag en handling - også de handlinger, der kan virke uforståelige eller overdrevne. De ”værktøjer", jeg er ved at afprøve er ikke en hammer og en skruetrækker, som i et svup-tag kan få bugt med stress. Derimod kan jeg levere beskrivelser, som kan støtte, at vi kan bruge vores sunde fornuft i hverdagen i nogle svære situationer.

De foreløbige resultater viser, at det nye fokus på skam og reaktionsmønstre ikke blot er relevant og genkendeligt, men at både ledere og medarbejdere har opnået ny viden, der bidrager til at få en større forståelse af egne og andres behov. "Der er faldet en sten fra mit hjerte, fordi jeg pludselig har fundet ud af, hvorfor jeg havde så svart ved at sige fra. Og jeg kan jo se, at det, jeg troede jeg havde brug for, f.eks. at få mere ansvar, det var faktisk slet ikke det,jeg havde brug for. Tvartimod. Gid jeg havde vidst det dengang", fortæller en medarbejder til mig i et opfølgende interview. For at arbejde konkret i det daglige med de to reaktionsmønstre og understøtte dialoger, er jeg på baggrund af ønsker fra både ledere og medarbejdere ved at udvikle dialogkort, som skal understøtte de øvrige materialer. Lederen Mette siger herom:

”Det er vigtigt, at dialogerne hele tiden tager afsæt i den fælles viden, vi har om de to reaktionsmønstre. Én af mine medarbejdere foreslog, at man skal have materialet i hånden, når man bliver ansat, altså værsgo, det er sådan her, vi tænker om måden af interagere med hinanden på. Sådan tror jeg, at det bliver ude ved mig, fordi det har vakt så stor genklang”.

\section{G. Konklusion: Der skal to til god ledelse}

"Hvilke kompetencer forudsætter det at kunne mestre det arbejdsmarked, vi er en del af nu? Hvordan kan vi supplere vores faglige kompetencer med nogle af de andre kompetencer, som er nødvendige for at lykkes i et godt arbejdsliv? Der ligger en kompetenceudvikling i forhold til at skabe en forståelse af, at det er en ny måde, vi skal være medarbejder og leder på. Vi kan ikke blive ved med at gøre det samme”.

Fagchefen i Skanderborg kommune sætter her ord på den praktiske udfordring, som jeg med min forskning gerne vil bidrage med input til. Jeg foregiver ikke at have fundet en universel løsning på 
stressproblematikken, men de foreløbige resultater fra mit nye forskningsprojekt og de mange reaktioner, jeg får fra ledere og medarbejdere, der har læst eller hørt om min forskning, giver mig grund til at tro på, at jeg har ramt noget betydningsfuldt, som kan omsættes til relevante dialoger på arbejdspladsen. Med skam har jeg afdækket en stressfaktor, der ikke kun er relateret til at have for mange opgaver, men en følelsesmæssig afvisning af, at bære berettiget til ros, i hvert fald for nogle stresssituationer. Der skal ikke herske tvivl om, at fundet af skam naturligvis ikke er forbeholdt medarbejdere, men i lige så høj grad også findes hos ledere og dermed også udgør en stor belastning og kræver forskningsmæssig opmærksomhed. Fokus i denne artikel har dog været at belyse med afsæt i den ledelsesopgave, der er forbundet med fundet af skam hos medarbejdere. Der er imidlertid brug for mere forskning og videreudvikling mhp. at kunne afdække mere systematisk, hvorvidt et fokus på skam og de to reaktionsmønstre kan medvirke til at forebygge, at stressreaktioner skal eskalere så meget, at de for den enkelte påvirker arbejdsfunktionen i en sådan grad, at sygemelding fremstår som eneste udvej. Om de problemstillinger, der antænder konflikten kan henføres til privatlivet eller arbejdslivet gør for mig at se ikke fra eller til i den henseende. Centerlederen Charlotte på Plejecentret Sjælsø nikker:

”Vi skal finde en vej, hvor vi kan gå fremad her og hjælpe hinanden. Det handler jo om at fokusere på, at vi har brug for forskellige typer af støtte, og at vi har brug for mere støtte, jo mere stresset vi er. Ja, og det er uanset, om det er det ene eller andet der er skyld i det."

"INTET MENNESKE er en ø, en verden for sig; ethvert menneske er et stykke af fastlandet, en del af det hele”. Sådan skrev digteren og domprovsten John Donne engang i 1600-tallet, men de er værd at huske på, for vejen til et godt arbejdsfællesskab kræver blik for hinanden, og at ledere såvel som medarbejdere udvikler kompetencer til at se sig selv og andre - ikke mindst i situationer, hvor der er en skamfølelse på spil. Vi kan ikke blive ved med at gøre det samme.

\section{H. Perspektivering: Det tager tid at lære et nyt sprog}

Da min samarbejdspartner, Charlotte, skulle lære spansk, startede hun et sted, hvor de forsøgte at gøre det nemt for hende. Efter 5 år kunne hun stadigvæk kun bruge de samme 50 ord, så hun kontaktede en spansklærer, "Euduardo", som præsenterede hende for 6 forskellige grammatiske tilgange og bad hende gå i gang med at læse en helt almindelig roman - på spansk altså! Ikke 
tilpasset at hun var en dansker, der var i gang med at lære et nyt sprog, men simpelthen en bog, hvis målgruppe var spaniere, der kunne spansk. Charlotte fortalte mig, at hun begyndte at græde af ren frustration, da hun skulle terpe både grammatik og læse den spanske roman, men også at hun hurtigt så, at Eduardo havde ret, for hun havde også et stort passivt ordforråd pga. hendes mange ophold i Spanien. Hun kunne faktisk langt mere, end hun troede. Det samme vil I opleve. Jeg håber ikke, at I reagerer med at græde, som Charlotte gjorde. Men jeg er klar over, at det "sprog", jeg har præsenteret under navnet: "En ny anerkendelsespraksis", kan virke overvældende ved første møde, når I skal til at forholde jer til en ny måde at være sammen på, som kræver meget opmærksomhed samtidig med, at arbejdet skal passes. Jeg er imidlertid overbevist om, at I også har et "passivt" ordforråd, så der er masser at bygge på. Man er nødt til at have et bevidst fundament for at kunne mestre et nyt sprog. For Charlotte var og er det vigtigt, at hun tager til Spanien i ny og næ og praktiserer sit spanske. Det samme vil gælde for den nye anerkendelsespraksis. Den skal praktiseres for at blive en naturlig del af hverdagen. I starten vil det kræve en større opmærksomhed, end når der er arbejdet med den over tid, og den er blevet en naturlig del af måden at gå til hinanden på i arbejdsfællesskabet.

\section{Boks: Forskningsprojektet "Ledelse, arbejdsfællesskaber, kerneopgave og stress"}

Den 1. september 2017 indgik CBS et samarbejde med Fremfærd (et samarbejde mellem parterne på det kommunale arbejdsmarked), og tre kommuner om et udviklings- og forskningsprojekt, der udvikler og afprøver nye kommunikationsværktøjer til at arbejde forebyggende med stress på arbejdspladser med afsæt i min forskning og det dertilhørende fokus på skam som et nyt arbejdsmiljøproblem. Med en projektledelse fra parternes side bestående af KL, Forhandlingsfællesskabet og FOA er der i projektet fokus på at få de indkomne erfaringer udbredt til både ledere og medarbejdere på det offentlige arbejdsmarked. I Rudersdal kommune afprøves redskaber i samarbejde med ældreområde ved udvalgte områder fra hjemmeplejen og plejecentret Sjælsø. I Skanderborg kommune afprøves redskaber i samarbejde med børne-unge-området ved børnehusene Bifrost, Kildebjerg, Viften og Gyvelhøjen, mens Københavns Kommune har bidraget med empiri til de indledende afdækninger ved Center Nørrebro. I overensstemmelsen med Fremfærds fokus på at bidrage til at udvikle de kommunale kerneopgaver med en tilgang, hvor borgerne inddrages så meget som muligt, er de deltagende ledere og medarbejdere centrale sparringspartnere ift. udformningen af værktøjer. Projektet løber frem til 1. marts 2020 og kan følges på www.vpt.dk. Og www.sundledelse.dk. 


\section{Referencer}

Andersen, M. F., Kingston, M. (2016). Stop Stress - håndbog for ledere. København: KLIM.

Borg V. et al. (2010). Hvidbog om mentalt helbred, sygefravær og tilbagevenden til arbejde. Det Nationale Forskningscenter for Arbejdsmiljø.

Foucault, M. (1985). Use of Pleasure: The History of Sexuality. New York: Vintage Books. Kvale, S., og Brinkmann, S. (2009). Interview - Introduktion til et håndværk. København: Hans Reitzel.

Ladegaard, Y. K., Skakon, J., Friis Elrond, J. og Netterstrøm, B. (2017): “How do line managers experience and handle the return to work of employees on sick leave due to work-related stress? A one-year follow-up study", i Disability and Rehabilitation, . September 2017.

Lazarus, R. S. (2006). Stress og følelser - en ny syntese. København: Akademisk Forlag.

Lewis, H. B. (1971). Shame and Guilt in Neurosis. International University Press.

Lindsay-Hartz, J., de Rivera, J. og Mascolo, M. (1995): Differentiating Guilt and Shame and their Effects on Motivation. In J. P. Tangney og K. W. Fischer. (red.): The Psychology of Shame, Guilt and Embarassment and Pride (pp. 274-300). New York: Guilford Press.

Matzau, M. (2011). Stresscoaching - hvor går grænsen? - 4 myter, der skaber mere stress. Erhvervspsykologi, 3.

Nathanson, D. L. (1992). Shame and Pride: Affects, Sex, and the Birth of the Self. W.W. Norton, New York.

OECD (2015). Fit mind, fit job: From Evidence to Practice in mental Health and Work, Mental Health and Work.

Raffnsøe, S., Thaning, M. S., og Gudmund-Høyer, M. (2015). Michel Foucault: A Research Companion (1st ed. 2015 edition). Palgrave Macmillan.

Pedersen, P. S. (2016a). Udkast til et nyt coping-begreb - en kvalifikation af ledelsesmuligheder for at forebygge sygefravær ved psykiske problemer. CBS. Ph.d.-serie 05/2016.

Pedersen, P.S. (2016b). Slip stress ud af skammekrogen - et forsvar for arbejdsfællesskabet. København: Kristelig Dagblads Forlag. 
Pedersen, P.S, Gudmand-Høyer, M. (2017). Modsatrettede forpligtelser: Skam og stress i arbejdslivet, Erhvervspsykologi, vol. 15.

Pedersen, P.S, Krarup, T. (2018). Foucault og problematiseringsanalyse, en analysemodel, i: Kvalitative analysemetoder i sundhedsforskning, Gilberg, Frederik Alkier og Hounsgaard, Lise. København. Forlaget Klim.

Tangney, J. P., Stuewig, J. og Mashek, D. J. (2007). “Moral Emotions and Moral Behavior”, Annual Review of Psychology, 58(1), 345-372.

https://doi.org/10.1146/annurev.psych.56.091103.070145 